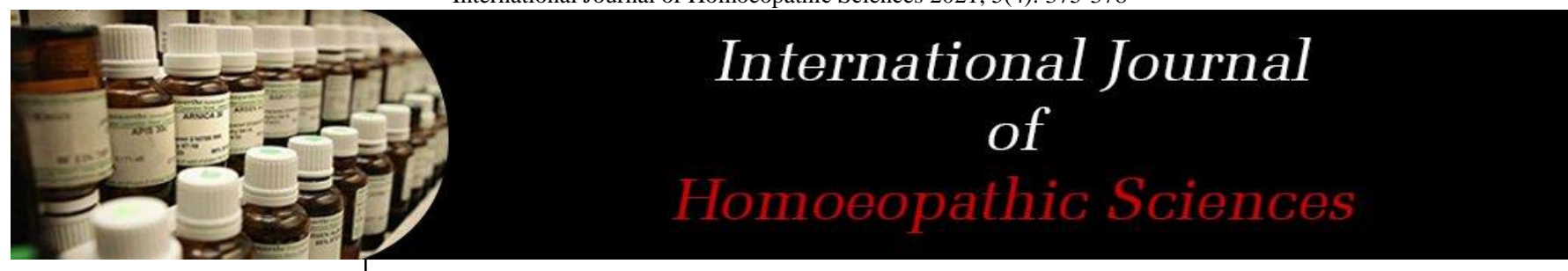

E-ISSN: $2616-4493$

P-ISSN: 2616-4485

www.homoeopathicjournal.com IJHS 2021; 5(4): 375-378

Received: 07-05-2021

Accepted: 16-07-2021

Sandra Babu V

IVth year BHMS Student,

Alva's Homoeopathic Medical

College, Mijar, Moodbidri,

Karnataka, India

\section{Maria Dhivya}

Associate Professor and

Research in Charge,

Department of Homoeopathic

Pharmacy, MNR

Homoeopathic Medical

College, Sangareddy,

Telangana, India

Yusuf Jamil M Qadri

Professor and HOD,

Department of Homoeopathic

Pharmacy, Alva's

Homoeopathic Medical

College, Mijar, Moodbidri,

Karnataka, India
Corresponding Author:

Sandra Babu V

IVth year BHMS Student,

Alva's Homoeopathic Medical

College, Mijar, Moodbidri,

Karnataka, India

\section{A human pathogenetic trial gratiola micrantha}

\author{
Sandra Babu V, Maria Dhivya and Yusuf Jamil M Qadri
}

DOI: https://doi.org/10.33545/26164485.2021.v5.i4f.498

\section{Abstract}

Background: Double blind randomized drug proving of Gratiola micrantha. The objective of this work is to know the curative power of drug and identify the action of this medicine.

Keywords: Gratiola micrantha, Double blind, Drug proving, Homoeopathic pathogenetic trail, Placebo, Homoeopathy, placebo- controlled trail

\section{Introduction}

Homoeopathic is based on the principles of "like cures like (Similia Similibus Curentur)" where that which causes a certain symptom picture when administered in infinitesimal doses to a healthy individual will also cure the same morbific symptoms presents in a sick individual. Kerala has wealth of indigenous plants and animals, which on yet have not been homeopathically proved and which could potentially play a significant role in treating commonly occurring health problems. Gratiola micrantha belongs to the family Plantagenaceae. Gratiola micrantha used traditionally as a medicine for renal calculi, increase urine output and seminal calculi in Ayurveda. Authors had proved Gratiola micrantha homeopathically by double blind human pathogenic trail.

\section{Materials and Methods: Study design and study setting}

A randomized, double blind, placebo-controlled study was conducted at Karnataka. The drug was purchased from the Kerala. The moisture content test for Gratiola micrantha was conducted at Department of Homoeopathic Pharmacy. Mother tincture of Gratiola micrantha and Gratiola micrantha $30 \mathrm{CH}$ prepared in the Department of Homoeopathic Pharmacy.

\section{Subjects}

Selection of provers: An initial screening was scheduled to shortlist the eligible candidate based on inclusion and exclusion criteria of $\mathrm{CCH}^{\prime}$ 's drug proving protocol. Informed consent form was obtained from eligible volunteers. A thorough pre proving case history and physical examination was performed on each of the provers by the researchers for duration of 2 weeks.

\section{Inclusion criteria}

- Apparently healthy individuals

- Healthy individuals are selected by experts

- Individuals must be able to record data such as facts, subjective and objective symptoms related to the proving with at most care.

- Able to informed the nature of the study

\section{Exclusion criteria}

- Any acute or chronic disease or condition

- Persons with color blindness

- Persons who has undergo surgery in last 2 months

- Volunteers on regular medication for any disease

- Smokers

- Hysterical and anxious persons

- Women during pregnancy, puerperium and while breast feeding

- Addictions like alcohol, drug

- Persons having allergic history 


\section{Procedure}

Randomization and blinding homoeopathic group, group $2(\mathrm{n}=15)$ : placebo group.

Intervention:

Placebo group: Placebo was made up of un medicated globules moisted with un medicated dispensing alcohol.

Homoeopathic group: Gratiola micrantha $30 \mathrm{CH}$ prepared in the Department of Homoeopathic Pharmacy. The globules

A starting date and convenient daily contact time for each prover was scheduled. The provers recorded the normal state in their daybook on a daily basis for two weeks. This served as a pre proving observation period to establish a baseline for each individual prover as well as an individual
Provers were randomized in 2 groups, group $1 \quad(n=15)$ : were medicated with medicine.

control for each prover. Each prover took the proving medication four times daily whilst continuing to note their symptoms in their journals. The prover had stopped taking the medicine as soon as new symptom is experienced after notifying the researcher. The prover continued to record their symptom until all proving symptoms disappeared. The proving was considered complete after 3 weeks when no further symptoms and signs occurred. All the day books were then collected from each prover and a post proving consultation was scheduled and conducted.

The data thus obtained was analyzed using George Vithoulkas grading system.

\section{Result and Discussion}

Table 1. Grading of symptoms according to Vithoulkas grading scale

\begin{tabular}{|c|c|c|c|c|c|c|c|c|c|c|}
\hline $\mathrm{SN}$ & Sympto ms & $\begin{array}{c}\text { Symptoms } \\
\text { appear } \\
\text { within } 7 \\
\text { Days of } \\
\text { starting } \\
\text { medicine } \\
\end{array}$ & $\begin{array}{c}\text { Sympto } \\
\text { m } \\
\text { strange/ } \\
\text { extra } \\
\text { ordinary }\end{array}$ & $\begin{array}{c}\text { Similar sympto } \\
\text { m in pre } \\
\text { observation } \\
\text { period/precedin } \\
\text { g } 30 \text { days }\end{array}$ & $\begin{array}{l}\text { Alternative } \\
\text { causes could } \\
\text { have caused } \\
\text { the reaction }\end{array}$ & $\underset{\text { Re }}{\operatorname{admin}}$ & \begin{tabular}{|c|} 
Strongly \\
associate the \\
symptom \\
with trail \\
medicine
\end{tabular} & $\begin{array}{c}\text { Symptom } \\
\text { improve } \\
\text { when trail } \\
\text { medicine } \\
\text { discontinued }\end{array}$ & \begin{tabular}{|} 
Symptom \\
also occur \\
with \\
placebo
\end{tabular} & $\begin{array}{l}\text { Repeti } \\
\text { tion of } \\
\text { medici } \\
\text { ne }\end{array}$ \\
\hline 1 & Talkative & +1 & 0 & +1 & +2 & 0 & +1 & 0 & +1 & 0 \\
\hline 2 & Sad feeling & +1 & 0 & -1 & +2 & 0 & -1 & 0 & +1 & 0 \\
\hline 3 & Uncomfo rtable & +1 & 0 & +1 & +2 & 0 & -1 & 0 & +1 & 0 \\
\hline 4 & Irritation & +1 & 0 & +1 & +2 & 0 & +1 & 0 & +1 & 0 \\
\hline 5 & Sluggish ness & +1 & 0 & +1 & +2 & 0 & +1 & +1 & +1 & 0 \\
\hline 6 & Confusio $\mathrm{n}$ & +1 & 0 & -1 & +2 & 0 & -1 & 0 & +1 & 0 \\
\hline 7 & Want to be alone & +1 & 0 & +1 & +2 & 0 & +1 & +1 & +1 & 0 \\
\hline 8 & Anxiety & +1 & 0 & -1 & +2 & 0 & -1 & +1 & +1 & 0 \\
\hline 9 & Unable to concentrate & +1 & 0 & -1 & +2 & 0 & -1 & 0 & +1 & 0 \\
\hline 10 & Tiredness & +1 & 0 & +1 & +2 & 0 & +1 & +1 & +1 & 0 \\
\hline 11 & Prefer loose clothes & +1 & 0 & -1 & +2 & 0 & +1 & +1 & +1 & 0 \\
\hline 12 & Headache & +1 & 0 & -1 & +2 & 0 & +1 & 0 & -2 & 0 \\
\hline 13 & Headach e in right eyes & +1 & +3 & +1 & +2 & 0 & +1 & +1 & +1 & 0 \\
\hline 14 & $\begin{array}{c}\begin{array}{c}\text { Heaviness of } \\
\text { forehead }\end{array} \\
\end{array}$ & +1 & 0 & +1 & +2 & 0 & +1 & 0 & +1 & 0 \\
\hline 15 & $\begin{array}{l}\text { Heavines s of head } \\
\text { radiating to eyes }\end{array}$ & +1 & 0 & +1 & +2 & 0 & +1 & +1 & +1 & 0 \\
\hline 16 & Dandruff & -1 & 0 & +1 & +2 & 0 & -1 & 0 & +1 & 0 \\
\hline 17 & Hair fall< Combing & -1 & 0 & +1 & +2 & 0 & -1 & 0 & +1 & 0 \\
\hline 18 & Giddiness & +1 & 0 & -1 & +2 & 0 & -1 & 0 & +1 & 0 \\
\hline \begin{tabular}{|l|}
19 \\
\end{tabular} & Itching in right eyes & +1 & 0 & +1 & +2 & 0 & +1 & +1 & +1 & 0 \\
\hline 20 & Lacrimat ion & +1 & 0 & +1 & +2 & 0 & +1 & +1 & +1 & 0 \\
\hline 21 & Eye strained feeling & +1 & 0 & -1 & +2 & 0 & +1 & +1 & +1 & 0 \\
\hline 22 & Intermittent earache & +1 & +3 & +1 & +2 & 0 & +1 & +1 & +1 & 0 \\
\hline 23 & Itching of nose & +1 & +3 & +1 & +2 & 0 & +1 & +1 & +1 & 0 \\
\hline 24 & Sneezing & +1 & 0 & -1 & +2 & 0 & +1 & 0 & +1 & 0 \\
\hline 25 & Nose block & +1 & +3 & +1 & +2 & 0 & +1 & 0 & +1 & 0 \\
\hline 26 & Continuo us coryza & +1 & 0 & -1 & +2 & 0 & -1 & 0 & +1 & 0 \\
\hline 27 & Dry mouth & +1 & 0 & +1 & +2 & 0 & -1 & 0 & +1 & 0 \\
\hline 28 & Throat pain & +1 & 0 & -1 & +2 & 0 & -1 & 0 & $+1+$ & 0 \\
\hline 29 & Hoarseness of voice & +1 & 0 & +1 & +2 & 0 & +1 & 0 & +1 & 0 \\
\hline 30 & Difficult y to talk & +1 & 0 & +1 & +2 & 0 & +1 & +1 & +1 & 0 \\
\hline 31 & Dryness of throat & +1 & 0 & +1 & +2 & 0 & +1 & 0 & +1 & 0 \\
\hline 32 & Throat irritation & +1 & 0 & +1 & +2 & 0 & +1 & +1 & +1 & 0 \\
\hline 33 & Stomach ache $<$ fasting & +1 & 0 & +1 & +2 & 0 & +1 & +1 & +1 & 0 \\
\hline 34 & Thirst for cold water & +1 & 0 & -1 & +2 & 0 & -1 & 0 & +1 & 0 \\
\hline 35 & Desire for sweet & +1 & 0 & -1 & +2 & 0 & -1 & 0 & +1 & 0 \\
\hline 36 & Loose stools & +1 & 0 & +1 & +2 & 0 & +1 & 0 & +1 & 0 \\
\hline 37 & Watery stools & +1 & 0 & +1 & +2 & 0 & +1 & 0 & +1 & 0 \\
\hline 38 & $\begin{array}{c}\text { Increase d urge for stools } \\
\text { during diarrhea }\end{array}$ & +1 & 0 & +1 & +2 & 0 & +1 & 0 & +1 & 0 \\
\hline \begin{tabular}{|l|}
39 \\
\end{tabular} & Frequent micturiti on & +1 & 0 & +1 & +2 & 0 & +1 & 0 & +1 & 0 \\
\hline
\end{tabular}




\begin{tabular}{|c|c|c|c|c|c|c|c|c|c|c|}
\hline 40 & Burning micturiti on & +1 & 0 & -1 & +2 & 0 & -1 & 0 & +1 & 0 \\
\hline 41 & $\begin{array}{c}\text { Difficult y in } \\
\text { urination }\end{array}$ & +1 & 0 & +1 & +2 & 0 & +1 & 0 & +1 \\
\hline 42 & $\begin{array}{c}\text { Difficult y in Urination } \\
\text { >after urination }\end{array}$ & +1 & 0 & +1 & +2 & 0 & +1 & 0 & +1 \\
\hline 43 & Breathin g difficulty & +1 & 0 & -1 & +2 & 0 & -1 & 0 & +1 & 0 \\
\hline 44 & Cough with sputum & +1 & 0 & -1 & +2 & 0 & -1 & 0 & +1 & 0 \\
\hline 45 & Cough <night & +1 & 0 & +1 & +2 & 0 & +1 & 0 & +1 & 0 \\
\hline 46 & $\begin{array}{c}\text { Dry cough with throat } \\
\text { irritation }\end{array}$ & +1 & 0 & +1 & +2 & 0 & +1 & 0 & +1 & 0 \\
\hline 47 & Right sided leg pain & +1 & 0 & +1 & +2 & 0 & +1 & 0 & +1 & 0 \\
\hline 48 & Joint pain & +1 & 0 & -1 & +2 & 0 & -1 & 0 & +1 & 0 \\
\hline 49 & Sleep disturbed & $+!$ & 0 & +1 & +2 & 0 & +1 & 0 & +1 & 0 \\
\hline 50 & Nightma res & +1 & 0 & +1 & +2 & 0 & +1 & 0 & +1 & 0 \\
\hline 51 & Feverish feeling & +1 & 0 & -1 & +2 & 0 & -1 & 0 & +1 & 0 \\
\hline 52 & Tirednes s & +1 & 0 & -1 & +2 & 0 & -1 & 0 & +1 & 0 \\
\hline 53 & Body pain & +1 & 0 & -1 & +2 & 0 & -1 & 0 & +1 & 0 \\
\hline 54 & Itching all over the body & +1 & 0 & -1 & +2 & 0 & -1 & 0 & +1 & 0 \\
\hline
\end{tabular}

Table 2: Cumulative score of Vithoulkas grading scale

\begin{tabular}{|c|c|}
\hline Symptoms & Grade \\
\hline Talkative & 6 \\
\hline Sad feeling & 2 \\
\hline Uncomfortable & 4 \\
\hline Irritation & 6 \\
\hline Sluggishness & 7 \\
\hline Confusion & 2 \\
\hline Want to be alone & 7 \\
\hline Anxiety & 3 \\
\hline Unable to concentrate & 2 \\
\hline Tiredness & 7 \\
\hline Prefer loose clothes & 5 \\
\hline Headache & 1 \\
\hline Headache in right eye & 10 \\
\hline Heaviness of forehead & 6 \\
\hline Heaviness of head radiating to \\
eyes & 7 \\
\hline Dandruff & 2 \\
\hline Hair fall < Combing & 2 \\
\hline Giddiness & 2 \\
\hline
\end{tabular}

\begin{tabular}{|c|c|}
\hline Itching in right eyes & 7 \\
\hline Lacrimation & 7 \\
\hline Eye strained feeling & 5 \\
\hline Intermittent earache & 10 \\
\hline Itching of nose & 10 \\
\hline Sneezing & 4 \\
\hline Nose block & 9 \\
\hline Continuous coryza & 2 \\
\hline Dry mouth & 4 \\
\hline Throat pain & 2 \\
\hline Hoarseness of voice & 6 \\
\hline Difficulty to talk & 7 \\
\hline Dryness of throat & 6 \\
\hline Throat irritation & 7 \\
\hline Stomach-ache < Fasting & 7 \\
\hline Thirst for cold water & 2 \\
\hline Desire for sweets & 2 \\
\hline Loose stools & 6 \\
\hline Watery stools & 6 \\
\hline Increased urge for stools & 6 \\
\hline
\end{tabular}

\begin{tabular}{|c|c|}
\hline during diarrhoea & \\
\hline Frequent micturition & 6 \\
\hline Burning micturition & 2 \\
\hline $\begin{array}{c}\text { Difficulty in urination } \\
\text { Difficulty in urination > After } \\
\text { urination }\end{array}$ & 6 \\
\hline Breathing difficulty & 2 \\
\hline Cough with sputum & 2 \\
\hline Cough < night & 6 \\
\hline $\begin{array}{c}\text { Dry cough with throat } \\
\text { irritation }\end{array}$ & 6 \\
\hline Right sided leg pain & 6 \\
\hline Joint pain & 2 \\
\hline Sleep disturbed & 6 \\
\hline Nightmares & 6 \\
\hline Feverish feeling & 2 \\
\hline Tiredness & 2 \\
\hline Body pain & 2 \\
\hline Itching all over the body & 2 \\
\hline
\end{tabular}

\section{Symptoms of Gratiola Micrantha Drug: Gratiola Micrantha \\ Potency: 30C \\ Number of provers: 30 \\ Mind}

- Talkative

- Sad feeling

- Uncomfortable

- Irritation

- Sluggishness

- Confusion

- Want to be alone

- Anxiety

- Unable to concentrate

\section{General}

- Tiredness

- Prefer loose clothes

Head

- Headache

- Headache in right eyes

- Heaviness of forehead
- Heaviness of head radiating to eyes

- Dandruff

- Hair fall < combing

- Giddiness

Eyes

- Itching in right eyes

- Lacrimation

- Eye strained feeling

Ear

- Intermittent ear ache

Nose

- Itching of nose

- Sneezing

- Nose block

- Continuous coryza

Mouth

- Dry mouth

Throat

- Throat pain 
- Hoarseness of voice

- Difficulty to talk

- Dryness of throat

- Throat irritation

\section{Stomach}

- Stomachache < fasting

- Thirst for cold water

- Desire for sweets

\section{Rectum}

- Loose stools

- Watery stools

- Increased urge for stools during diarrhea

\section{Urinary}

- Frequent micturition

- Burning micturition

- Difficulty in urination

- Difficulty in urination > after urination

\section{Respiratory}

- Breathing difficulty

\section{Cough}

- Cough with sputum

- Cough < night

- Dry cough with throat irritation

\section{Extremities}

- Right sided leg pain

- Joint pain

Sleep

- Sleep disturbed

- Nightmares

Fever

- Feverish feeling

- Tiredness

- Body pain

\section{Skin}

- Itching all over the body

Researcher conducts daily discussion and understanding of the symptoms with provers and after repeated evaluation and study the drug picture of Gratiola Micrantha was formed.

\section{Conclusion}

The final report shows the curative power and action of the drug. Prominent specific symptoms observed in the drug are headache in right eyes, intermittent earache, itching of nose, nose block.

In this study, the drug under investigation is administered and the individual response of the individual is described, which can be stated as a bird's eye view on the drug. Further detailed drug proving must be done, followed by re drug proving on major group and clinical proving before approval. According to the law of similar, the substance is then used to treat patients with similar symptoms.

\section{Acknowledgement}

This work was funded by Rajiv Gandhi University of Health
Sciences, Bangalore under student's research Grant 2019-20 with Rs 15000/-

\section{References}

1. Samuel Hahnemann. Organon of medicine: 5 th edition with an appendix by R.E Dudgeon with additions \& Alternations of 6th Edition translated by William Boericke \& Introduction by James Krauss - B. Jain Publishers

2. Stuart Close. The Genius of Homoeopathy Lectures \& Essay on Homoeopath Philosophy, Reprint Edition 2005 - 2006 - B. Jain Publishers New Delhi

3. HA Robert, MD> The Principles \& Art of cure by Homoeopathy. A modern textbook with word index, 3rd Edition 10th Impression 2014 - B.Jain Publishers New Delhi 2005.

4. Partha Partian Mandal, Biman Mandal. Textbook of Homoeopathy Pharmacy Reprinted New Central book Agency Calcutta 2002.

5. Dr. Banerjee DD. The Textbook of Homoeopathic Pharmacy Reprinted B. Jain Publishers New Delhi 2002.

6. Dr. Sumit Goel. Art \& Science of Homoeopathic Pharmacy 2nd enlarged \& revised Edition Mind Technologies Mumbai 2007. 